\title{
KONTEKSTUALISASI GAMELAN JAWA DI GEREJA BAPTIS INDONESIA (GBI) NGEMBAK
}

\author{
Alfa Kristanto \\ STT Abdiel Ungaran \\ alfaomega.kristanto@gmail.com
}

\begin{abstract}
Abstrak
Penelitian ini bertujuan untuk menganalisis kontekstualisasi gamelan Jawa dalam liturgi ibadah di GBI Ngembak Tembalang. Pendekatan yang digunakan adalah interdisiplin dengan menggunakan metode penelitian kualitatif, dan desain penelitian studi kasus interpretatif. Data penelitian dikumpulkan dengan teknik observasi, wawancara, dan studi dokumen, serta teknik triangulasi sumber untuk menjaga validitasnya. Teknik analisis data dilakukan melalui proses reduksi, penyajian, dan penarikan simpulan (verifikasi). Hasil penelitian ini menunjukkan bahwa, kontekstualisasi gamelan Jawa dalam liturgi ibadah di Gereja Baptis Indonesia (GBI) Ngembak Tembalang terdiri dari satu model, yaitu model terjemahan. Pada model terjemahan tersebut dilakukan melalui upaya pelestarian jati diri Kristen, dengan tetap memperhatikan kebudayaan, perubahan sosial, dan sejarah yang dimiliki oleh Gereja Baptis Indonesia (GBI) Ngembak Tembalang.
\end{abstract}

Kata kunci: gamelan; kontekstualisasi; liturgi

\begin{abstract}
This thesis aims to examine contextualization of Javanese gamelan in the liturgy of the worship at the Indonesian Baptist Church (GBI) Ngembak Tembalang. The approach used is interdisciplinary, using qualitative research methods, and interpretative case study research design. The research data was collected by observation technique, interview, and document study, and source triangulation technique to maintain its validity. Data analysis technique is done through the process of reduction, presentation, and conclusion (verification). The results of this study show that, the form of Javanese gamelan accompaniment music in liturgical worship at GBI Ngembak Tembalang is composed of two elements, namely the element of time and melody. Contextualization of Javanese gamelan in the liturgy of the worship at the Indonesian Baptist Church (GBI) Ngembak Tembalang consists of one model, namely model translation. On the model of translation is done through the efforts of Christian identity preservation, keeping mindful of the culture, history and social change, which is owned by the Baptist Church Indonesia (GBI) Ngembak Tembalang.
\end{abstract}

Keywords: gamelan; contextualization; liturgy.

\section{Pendahuluan}

Seni tradisional merupakan kebudayaan yang patut dan penting untuk mendapatkan perhatian karena kebudayaan merupakan identitas dari suatu bangsa, sehingga kebudayaan sangat erat hubungannya dengan masyarakat. Danandjaja (dalam Darma, 2011, p. 55) bahwa nilai-nilai tradisi masyarakat terwujud dalam berbagai bentuk, di antaranya ceritacerita lisan yang merupakan bagian dari folklor dan menjadi sebuah warisan budaya. Kesenian tradisional yang sarat dengan nilai-nilai budaya seyogyanya dapat menjadi sarana pewarisan bagi generasi penerus bahkan menjadi identitas suatu daerah, dikarenakan seni 
sebagai produk budaya mampu merefleksikan ekspresi simbolik suatu budaya masyarakat tertentu (lihat Murni, Rohidi, dan Syarif, 2016, p. 155).

Salah satu dari banyak contoh kesenian tradisional di Indonesia adalah gamelan Jawa. Gamelan Jawa merupakan seperangkat instrumen sebagai pernyataan musikal yang sering disebut dengan istilah karawitan. Karawitan (berasal dari bahasa Jawa: rawit) yang berarti rumit, berbelit-belit, tetapi rawit juga berarti halus, cantik, berliku-liku, dan enak. Kata Jawa karawitan khususnya dipakai untuk mengacu kepada musik gamelan, yang bersistem nada pentatonis (dalam laras slendro dan pelog). Pengertian secara umum, gamelan ialah alat musik tradisional Jawa, Bali, dan Sunda yang pada dasarnya menggunakan laras slendro dan pelog. Laras ialah susunan nada yang di dalam satu oktaf intervalnya sudah tertentu. Di dalam karawitan ada dua laras, yaitu laras slendro dan laras pelog (Soedarsono, 1998, p. 19). Seni sebagai bagian dari kebudayaan, tidak terlepas dari pengaruh perubahan sosial. Perubahan seni banyak dipengaruhi pula oleh faktor nonestetis, politik, religi, dan sosial.

Menurut Suwaji Bastomi (1992, p. 113) Gamelan adalah permainan musik jawa yang bagian-bagiannya berupa alat perkusi yang dibuat dari perunggu (gangsa). Gangsa berasal dari kata Gasa artinya perbandingan antara timah: tembaga adalah 3 (tiga) : 10 (sedasa). Namun ada pula gamelan yang dibuat dari besi. Pemainnya disebut "pradangga", penyanyinya disebut "waranggana". Waranggana berasal dari kata wara artinya penyanyi, anggana artinya tunggal. Waranggana berarti penyanyi tunggal. Soeroso (1993, p. 12-14) mengungkapkan bahwa seperangkat Gamelan Ageng laras slendro dan laras pelog terdiri atas beberapa macam instrumen yang setiap jenis satuannya disebut ricikan. Ditinjau dari bentuk, bahan, dan cara memainkannya seperangkat Gamelan Ageng dapat digolongkan menjadi jenis ricikan: bentuk tebokan, bentuk bilah, bentuk pencon, bentuk kawatan dan bentuk pipa. Gamelan Jawa terdiri dari instrumen yaitu kendang, bonang, bonang penerus, demung, saron, peking, kenong dan kethuk, slenthem, gender, gong, gambang, rebab, siter, dan suling.

Perkembangan musik di Gereja lebih banyak memanfaatkan band dibandingkan musik tradisional dalam mengiringi liturgi ibadah. Gereja-gereja yang memanfaatkan lagu himn dalam liturgi ibadah minggu cenderung menggunakan keyboard yang memanfaatkan model-model iringan di dalamnya. Budaya pop dewasa ini mulai berkembang di gereja pada umumnya. Budaya pop adalah budaya masyarakat pada umumnya yang hidup (lived culture) dalam kehidupan masyarakat kebanyakan, berkembang sejalan dengan 
perkembangan industrilisasi, produksi massa dan media massa, yang berkaitan dengan budaya massa (Piliang dalam Nafis, Minawati, dan Ediwar, 2014, p. 5). Fokus pada Gereja Baptis Indonesia di sekitar Semarang dijumpai adanya gamelan Jawa untuk mengisi pujian dalam liturgi ibadah. Ada sesuatu yang berbeda ketika melihat gamelan Jawa digunakan untuk mengiringi liturgi ibadah di GBI Ngembak Tembalang.

GBI umumnya menerapkan sistem pemerintahan Gereja yaitu konggregasional. Pelaksanaan ibadah di hari minggu sebanyak dua kali yaitu pada pagi dan sore. Pujian dalam ibadah di GBI Ngembak Tembalang menggunakan buku kidung dan lagu-lagu praise worship yang sesuai perkembangan sekarang. Rutinitas ibadah hari minggu di GBI Ngembak Tembalang menggunakan band sebagai pengiring lagu pujian dalam ibadah. Tetapi pada minggu terakhir dalam setiap bulan di GBI Ngembak Tembalang menggunakan gamelan Jawa untuk mengiringi ibadah di hari minggu pagi.

Penggunaan gamelan Jawa di GBI Ngembak terangkai dalam sebuah liturgi ibadah minggu. Perlu dipahami arti liturgi yaitu kata "liturgi" berasal dari bahasa Yunani: leitourgia. Asal katanya adalah laos artinya rakyat dan ergon artinya pekerjaan. Jadi, liturgi adalah pekerjaan publik atau pekerjaan yang dilakukan oleh rakyat/ jemaat secara bersama-sama (Martasudjito, 2005, p. 9-16). Dengan pengertian ini, dapat dikatakan bahwa "liturgi" adalah "ibadah." Setiap ibadah Kristen — apapun denominasinya—harus bersifat liturgis, artinya melibatkan setiap orang yang hadir di dalamnya. Maka ibadah yang di dalamanya jemaat hanya menjadi penonton pasif bukanlah ibadah dalam arti yang sesungguhnya.

Istilah kontekstualisasi telah digunakan secara populer dalam dunia pendidikan teologi pada dekade-dekade akhir abad XX ini. Konsep yang dikemukakan dan dipadukan dengan penalaran kontekstualisasi, maka akan diperoleh gambaran yang padu karena bermuara pada satu tujuan, yaitu bagaimana menjelaskan Injil dalam cultural frame work suatu budaya sehingga membawa keseimbangan yang dinampakkan dalam refleksi teologis yang alkitabiah dari kerangka budaya tersebut, di mana Yesus Kristus diterima sebagai Tuhan dan Juruselamat mereka dan Injil serta gereja adalah juga milik mereka (Tomatala, 1996, p. 9).

Kontekstualisasi sebagai istilah yang lebih diutamakan untuk menggambarkan teologi yang mengindahkan kebudayaan dan perubahan kebudayaan secara sungguhsungguh, mesti juga berupaya menjaga keseimbangan. Tidaklah cukup memusatkan perhatian secara eksklusif pada ihwal jati diri budaya, karena terlalu sering kita kehilangan 
jati diri itu dengan menjualnya kepada pemikiran modern dari Barat. Kita juga mesti menggubris regiositas kerakyatan, namun cara-cara lama tidak pernah boleh menghalangi upaya menjadikan Injil sebagai tantangan dan sekaligus kabar gembira yang benar-benar nyata dan ada (Bevans, 2000, p. 48).

Kontekstualisasi pada umumnya dipahami sebagai upaya dan proses menyalurkan, mengkomunikasikan dan membawa berita Injil ke dalam konteks tertentu. Kontekstualisasi di samping berkaitan dengan upaya mengkomunikasikan Injil dalam konteks tertentu, juga berkaitan dengan ibadah, musik dan nyanyian Gerejawi atau menyangkut unsur-unsur tata cara ibadah. Kontekstualisasi liturgi dapat dipahami sebagai proses menyesuaikan, menerjemahkan, menyalurkan, mengkomunikasikan, mewujudkan, menghayati unsurunsur dan aspek liturgi di dalam konteks tertentu (Kirchberger, 2006).

Penelitian yang sudah dilakukan oleh Sukatmi Susantina mengenai gamelan jawa, membahas tentang konsep-konsep aksiologi dari para filsuf, nilai-nilai kesenian Jawa, serta dimensi aksiologis dalam proses inkulturatif (Susantina, 2001, p. 30). Sehingga dari hasil penelitian tersebut dapat memberikan sumbangsih pemikiran tersendiri bagi peneliti tentang kesenian Jawa.

Permasalahan dalam penelitian ini adalah kontekstualisasi gamelan Jawa dalam liturgi ibadah di GBI Ngembak. Teori yang digunakan untuk menjawab rumusan masalah yaitu teori kontekstualisasi dari stephen B. Bevans. Teori kontekstualisasi dari Stephen B. Bevans terdapat lima model yaitu, model terjemahan, model antropologis, model praksis, model sintesis, model transendental. Sedangkan model yang digunakan untuk menganalisis kontekstualisasi dalam penelitian ini yaitu model terjemahan. Konsep dalam model terjemahan yaitu seseorang memahami pewartaan Kristen dan berada dalam persinggungan yang kreatif dengan kebudayaan bersangkutan. Konsep kedua yaitu peran pembantu atau subordinasi kebudayaan dalam proses kontekstualisasi.

\section{Metode Penelitian}

Pendekatan yang digunakan adalah kualitatif yang secara rinci menggunakan desain penelitian studi kasus. Desain penelitian ini dipilih untuk meneliti fenomena kesenian gamelan Jawa dalam liturgi ibadah di GBI Ngembak. Hal tersebut dilakukan dengan menginterpretasikan berbagai teori-teori dan konsep-konsep kontekstualisasi yang terkait dengan fokus penelitian yaitu kontekstualisasi gamelan Jawa. Kontekstualisasi merupakan teori dari disiplin Ilmu Teologi Kristen. Lokasi yang dipilih yaitu di GBI 
Ngembak, karena instrumen gamelan Jawa digunakan penuh dalam liturgi ibadah Minggu. Sumber data dalam penelitian ini dibedakan menjadi dua, yaitu sumber data primer melalui wawancara dengan pemain gamelan, gembala jemaat, jemaat, dan observasi pertunjukan gamelan Jawa dalam liturgi ibadah Minggu, sedangkan sumber data sekunder diperoleh melalui kepustakaan, arsip, dokumen sejarah, dan buku-buku yang relevan dengan penelitian.

Data penelitian dikumpulkan dengan menggunakan teknik observasi, wawancara, dan studi dokumen. Seperti yang dikemukakan Sumaryanto (2007, p. 113) bahwa data atau dokumen yang diperoleh pada penelitian kualitatif (khususnya naturalistik) perlu diperiksa keabsahannya supaya menjadi penelitian yang terdisiplin atau ilmiah, sehingga untuk pengabsahan data, peneliti menggunakan teknik triangulasi sumber dan data. Teknik analisis data yang digunakan mengacu pada model interaktif dari Miles dan Huberman dalam Rohidi (2011, p. 240), melalui proses pengumpulan, reduksi, penyajian, dan penarikan simpulan (verifikasi) data.

\section{Kontekstualisasi Gamelan Jawa di GBI Ngembak Tembalang}

Analisis kontekstualisasi gamelan Jawa dalam liturgi ibadah di GBI Ngembak menggunakan disiplin ilmu Teologi. Ilmu Teologi digunakan untuk menganalisis kontekstualisasi dengan menggunakan konsep dari Bevan (2000, p. 48) sebagai acuan peneliti untuk menjawab permasalahan penelitian.

Pembahasan hasil penelitian untuk menjawab permasalahan secara tuntas, peneliti juga menambahkan berbagai konsep lain yang relevan untuk mendukung dan melengkapi hasil penelitian. Hal ini dikarenakan atas dasar pemikiran etik dan emik yang bertujuan menjaga objektivitas pada pembahasan penelitian yang dipaparkan oleh peneliti.

\section{Model Terjemahan}

Model yang digunakan untuk menganalisis kontekstualisasi dalam penelitian ini yaitu model terjemahan. Konsep dalam model terjemahan yaitu seseorang memahami pewartaan Kristen dan berada dalam persinggungan yang kreatif dengan kebudayaan bersangkutan. Konsep kedua yaitu peran pembantu atau subordinasi kebudayaan dalam proses kontekstualisasi. 
Model terjemahan yang terdapat di GBI Ngembak, ditandai dengan adanya gamelan jawa kira-kira pada tahun 1980 dan gamelan itu dulunya merupakan milik Kepala Desa/ Lurah dari Karangjati. Saat itu mulai digunakan dalam ibadah minggu setiap bulan di minggu ke empat. Tetapi jika dalam minggu ke empat ada pengkhotbah tamu maka penggunaan gamelan dialihkan di minggu ke tiga. Masuknya gamelan Jawa sebagai alat musik yang mendukung pelaksanaan ibadah Minggu. Hal tersebut memiliki kesesuaian dengan model terjemahan dari Bevan (2000, p. 8) yaitu perhatian utama model terjemahan adalah pelestarian jati diri Kristen, sambil berupaya sungguh-sungguh mengindahkan sejarah.

Martono menjelaskan bahwa gamelan di GBI Ngembak ada sejak tahun 1980 dan saat itu nama pelatihnya adalah Jasupi tetapi saat ini sudah meninggal. Jasupi melatih gamelan di GBI Ngembak, yang dilatih yaitu bapak-bapak dan ibu-ibu. Keseriusan itu ditunjukan dengan respon jemaat untuk meluangkan waktu berlatih gamelan yang dipimpin oleh pelatihnya. Hal tersebut memiliki kesesuaian dengan model terjemahan dari Bevan (2000, p. 8) yaitu perhatian utama model terjemahan adalah pelestarian jati diri Kristen, sambil berupaya sungguh-sungguh mengindahkan sejarah.

Beberapa alasan dari GBI Ngembak masih menggunakan gamelan jawa dalam ibadah Minggu yaitu masih ada jemaat yang disebut generasi lama. Penggunaan gamelan jawa di GBI Ngembak merupakan salah satu wujud mempertahankan budaya. Di lingkup pemerintahan, GBI Ngembak dikenal sebagai gereja yang memiliki gamelan beserta penabuhnya.

Pemaparan sejarah masuknya gamelan di GBI Ngembak merupakan bentuk kontekstualisasi dalam model terjemahan. Penjelasan terkait pertimbangan jemaat GBI Ngembak yang masih menggunakan gamelan sebagai wujud kontekstualisasi. Hal ini menunjukan terjadi kesesuaian dengan model terjemahan dari Bevan (2000, p. 8) yaitu perhatian utama model terjemahan adalah pelestarian jati diri Kristen, sambil berupaya sungguh-sungguh mengindahkan sejarah.

Gamelan Jawa di GBI Ngembak pada waktu dahulu ternyata dapat menarik simpati masyarakat sekitar. Komunikasi seni menjadi hal yang penting dalam sebuah peristiwa seni yang menyampaikan pesan/ makna di dalamnya. Seperti yang dikemukakan oleh Kayam (dalam Lohanda, 1983, p. 141) bahwa komunikasi seni antara pencipta dan pendukung amat didasari oleh rasa keakraban, yang berarti kemampuan kedua belah pihak untuk saling menangkap dan memberi makna dari penciptaan seni. Hal senada juga dikemukakan 
oleh Jaeni (2012, p. 161-162) bahwa tidak sedikit pergelaran seni pertunjukan ditinggalkan oleh penontonnya atau dinilai gagal, baik pertunjukan drama, tari, maupun musik, bukan semata karena pertunjukan itu tidak didukung oleh personil yang baik, perlengkapan yang serba modern atau kemegahan panggung dengan kekuatan tata cahaya dan tata suara yang mengagumkan. Namun juga dikarenakan tidak mampu memberikan informasi nilai-nilai yang disepakati masyarakatnya.

Penjelasan tersebut dapat diinterpretasikan bahwa suatu komunikasi seni dapat berjalan secara timbal balik ketika terdapat kesesuaian kemampuan antara pencipta (seniman) dan pendukung (penonton) untuk dapat saling menangkap dan memberi makna dari peristiwa seni. Beberapa orang yang beragama Islam turut memainkan alat musik siter dan kendang bersama dengan anggota jemaat GBI Ngembak. Terdapat kemungkinan bahwa semangat yang dimiliki saat itu adalah gamelan dipahami sebagai salah satu alat musik tradisional yang patut mendapat perhatian untuk dipertahankan, sehingga masyarakat sekitar yang majemuk tersebut memahami keberadaan gamelan di GBI Ngembak bukan semata untuk kepentingan gerejawi saja. Namun seiring dengan perkembangan zaman, terjadi suatu perubahan yaitu pemain gamelan terdiri dari beberapa orang saja yang merupakan anggota jemaat GBI Ngembak. Hal tersebut memiliki kesesuaian dengan model terjemahan dari Bevan (2000, p. 8) yaitu perhatian utama model terjemahan adalah pelestarian jati diri Kristen, sambil berupaya sungguh-sungguh mengindahkan perubahan sosial.

Awal mula tujuan jemaat di GBI Ngembak mempunyai gamelan yaitu bukan untuk ibadah. Saat jemaat ada yang mengadakan pesta pernikahan lebih cenderung untuk menyewa musik organ tunggal sebagai media hiburan dalam pesta. Setelah GBI Ngembak memiliki gamelan maka ketika ada jemaat yang mengadakan pesta pernikahan dapat memanfaatkan gamelan untuk mengiringi pesta pernikahan. Sesudah itu, jemaat mempunyai keinginan supaya gamelan difungsikan dalam mengiringi ibadah di GBI Ngembak. Maka oleh pelatihnya mulailah dibuat aransemen untuk lagu-lagu yang digunakan dalam ibadah minggu di GBI Ngembak.

Semula gamelan digunakan untuk kepentingan hiburan, selanjutnya terjadi perubahan fungsi yaitu gamelan jawa digunakan sebagai alat musik untuk mengiringi ibadah minggu di GBI Ngembak. Fenomena yang sudah dipaparkan, dapat dipahami bahwa proses perubahan sosial budaya turut mempengaruhi perwujudan sebuah kesenian. Hasil penelitian lain, diantaranya Muniarti (2015) menunjukkan bahwa terjadinya 
perubahan dalam aspek bentuk, fungsi, makna, dan estetika musik gamat dipengaruhi oleh kreativitas musisi, selera konsumen, situasi perkembangan musik, tuntutan hiburan kekinian, dan pengaruh musik campursari (unsur budaya Jawa modern) yang berkembang dalam masyarakat Minangkabau. Selain itu, fenomena perubahan perwujudan seni juga dapat disebabkan oleh kreativitas seniman, teknologi, tuntutan pasar/ selera masyarakat (lihat Saepudin 2015; Romadhon 2013; Ruseli dan Minawati 2013; Ghofur dan Rini 2015).

Keberadaan gamelan di GBI Ngembak mulai didengar luas oleh masyarakat. Hal ini dibuktikan dengan tim gamelan dari GBI Ngembak pernah mengisi acara Natal di Citraland, pernah tampil di Telkom, pernah tampil di Karangawen, pernah tampil di Puspowarno. Artinya terdapat dinamika perubahan yang menarik untuk diungkapkan. Berawal dari gamelan yang difungsikan sebagai hiburan kemudian fungsi itu mengalami perubahan yaitu gamelan digunakan untuk mendukung dalam ibadah minggu, kemudian gamelan mulai mendapatkan tempat lebih luas di luar GBI Ngembak dalam fungsinya mengiringi ibadah. Beberapa perubahan yang terjadi dipengaruhi oleh luasnya relasi jemaat GBI Ngembak dengan masyarakat sekitarnya.

Perubahan sosial budaya merupakan satu kesatuan yang tidak dapat dipisahkan satu sama lainnya dan saling berkaitan (lihat Kaesthi 2014, p. 57). Perubahan sosial cenderung bersifat konstan, inkremental (gradual) yang diperkenalkan sedikit demi sedikit dalam kehidupan masyarakat dengan berbagai bentuk seperti teknologi baru, praktik institusional baru, bentuk-bentuk baru 'budaya' dan persyaratan perubahan tempat kerja (May 2011, p. 374). Hal tersebut memiliki kesesuaian dengan model terjemahan dari Bevan (2000, p. 8) yaitu perhatian utama model terjemahan adalah pelestarian jati diri Kristen dengan berupaya mengindahkan perubahan sosial.

Penggunaan gamelan dalam liturgi ibadah di GBI Ngembak mendapatkan respon yang beragam oleh jemaat. Jemaat merespon baik dengan penggunaan gamelan dalam liturgi ibadah Minggu. Tetapi ada hal yang perlu diperhatikan yaitu ada perbedaan jumlah kehadiran jemaat saat ibadah menggunakan iringan gamelan dibanding dengan menggunakan iringan band. Jika ibadah menggunakan iringan gamelan maka kehadiran jemaat mencapai sekitar 120 orang, sedangkan ketika menggunakan iringan band maka kehadiran jemaat sekitar 150 orang. Jemaat yang berusia muda lebih cenderung memilih penggunaan band dalam liturgi ibadah dan jemaat yang berusia tua lebih cenderung memilih penggunaan gamelan dalam mengiringi liturgi ibadah. Kehadiran gamelan di GBI Ngembak membawa pengaruh dan perubahan khususnya kehadiran jemaat saat ibadah di 
hari Minggu. GBI Ngembak menggunakan gamelan dalam mengiringi liturgi ibadah yaitu setiap satu kali dalam satu bulan dan biasanya dalam minggu terakhir dalam setiap bulannya.

Perubahan sosial budaya dapat disebabkan oleh adanya media dengan bantuan teknologi yang semakin canggih, berperan dalam menanamkan the pictures in our heads, mendasari respon dan sikap khalayak terhadap berbagai objek sosial (lihat Kango 2015; Hernawan 2012). Perubahan terjadi sesuai dengan hakikat dan sifat dasar manusia yang selalu ingin mengadakan perubahan (Setiawati dan Sanjoyo, 2012, p. 73). Menurut Sayogyo dalam Siregar dan Kinseng (2015, p. 15) menjelaskan bahwa faktor pendukung terjadinya perubahan sosial yaitu intensitas hubungan atau kontak dengan kebudayaan lain, tingkat kebudayaan yang maju, sikap terbuka dari masyarakat, dan sikap ingin berkembang dan maju dari masyarakat.

Meskipun ada perbedaan jumlah kehadiran jemaat saat menggunakan gamelan dibanding menggunakan band dalam mengiringi liturgi ibadah minggu, tetapi tidak ada perbedaan liturgi antara ibadah diiringi gamelan dibanding band. GBI Ngembak menggunakan liturgi yang sama meskipun diiringi oleh alat musik yang berbeda. Ada hal berbeda ketika menggunakan iringan gamelan saat ibadah, yaitu di saat awal ibadah ada instrumen selama 15 menit sebelum ibadah dimulai. Pemain gamelan menabuh gamelan lebih awal sebelum ibadah dimulai, dan tersirat makna bahwa permainan musik gamelan adalah sedang menyambut kehadiran jemaat dan mengantarkan jemaat untuk masuk dalam ibadah. Dapat dipahami bahwa jemaat di GBI Ngembak mendukung kontekstualisasi yang mengindahkan perubahan sosial. Hal tersebut memiliki kesesuaian dengan model terjemahan dari Bevan (2000, p. 8) yaitu perhatian utama model terjemahan adalah pelestarian jati diri Kristen, sambil berupaya sungguh-sungguh mengindahkan perubahan sosial.

Ada perbedaan diantara pelatih terkait aransemen yang dibuat untuk gamelan. Aransemen yang pertama yaitu iringan gamelan melodi tunggal sama persis dengan melodi utama dalam lagu. Aransemen yang kedua yaitu iringan gamelan mengacu dari melodi utama lagu kemudian dibuat harmoninya. Martono membuat aransemen dengan pemikiran bahwa gamelan ini adalah untuk mengiringi orang menyanyi, dibanding pemikiran Jasupi yaitu ketika jemaat menyanyi maka iringan gamelan sama persis dengan melodi lagu yang dinyanyikan oleh jemaat. Martono banyak membuat aransemen untuk gamelan yang berdasar dari buku Nyanyian Pujian, Nyanyian Harian, dan dari kaset. Unsur-unsur 
pembentuk sebuah musik tentunya tidak terlepas dari adanya bunyi yang diolah sedemikian rupa oleh seniman. Seperti yang dikemukakan Sugiartha (2015, p. 50) bahwa bunyi yang telah dimodifikasi oleh seniman secara realitas tampil dalam berbagai wujud, seperti ritme, melodi, harmoni, dan frekuensi, yang ditunjang oleh unsur-unsur musikal lainnya seperti tempo dan dinamika.

Aransemen yang dibuat oleh Martono menghasilkan 112 lagu yang dicetak dalam bentuk buku. Hasil aransemen dari Martono masih digunakan sampai saat ini ketika gamelan digunakan untuk mengiringi ibadah minggu. Di GBI Ngembak oleh Jasupi pemain gamelan yaitu terdiri dari bapak-bapak. Berubahnya waktu maka ada dinamika yang terjadi yaitu semakin berkurang bapak-bapak yang ikut berlatih untuk memainkan gamelan, hal ini kemungkinan disebabkan karena kesibukan kegiatan setiap individu pemain gamelan. Maka terjadi kekosongan pemain gamelan yang mengakibatkan sementara waktu tidak ada latihan gamelan karena tidak ada orang yang akan dilatih. Saat itu Jasupi melatih pemain gamelan di GBI Ngembak dengan menggunakan lagu-lagu Nasional.

Berbeda ketika Martono menjadi pelatih gamelan di GBI Ngembak, yaitu pemain gamelan terdiri dari ibu-ibu. Lagu-lagu yang dilatihkan yaitu lagu-lagu rohani meskipun Martono bisa untuk melatihkan lagu-lagu nasional. Jemaat di GBI Ngembak mendukung kontekstualisasi yang memperhatikan upaya mengindahkan perubahan sosial. Meskipun terjadi perubahan aransemen dan pemain gamelan dari pelatih lama ke pelatih yang baru namun perubahan itu memiliki tujuan yang sama yaitu mendukung jemaat dalam melaksanakan ibadah. Seperti yang dijelaskan oleh Ratna dalam Supriyatna (2012, p. 80) bahwa eksistensi sebuah produk seni atau karya seni bukanlah semata-mata gejala individual, melainkan juga gejala sosial. Hal tersebut memiliki kesesuaian dengan model terjemahan dari Bevan (2000, p. 8) yaitu perhatian utama model terjemahan adalah pelestarian jati diri Kristen dengan sungguh-sungguh mengindahkan perubahan sosial.

Yosua sebagai salah satu jemaat mendukung keberadaan gamelan di GBI Ngembak dan kegunaannya dalam liturgi ibadah sebagai bentuk upaya melestarikan kebudayaan lokal dan perlu dikembangkan. Generasi muda sebagai generasi penerus maka perlu tahu cara memainkan gamelan dan cara membuat aransemennya. Harapannya yaitu ketika generasi tua sudah tidak ada maka sudah ada generasi muda yang akan melanjutkan tugasnya. Dapat dipahami bahwa mewakili generasi muda di GBI Ngembak, anak-anak muda mendukung upaya mengindahkan kebudayaan lokal yaitu gamelan Jawa sebagai alat 
musik dalam pelaksanaan ibadah Minggu. Hal tersebut memiliki kesesuaian dengan model terjemahan dari Bevan (2000, p. 8) yaitu perhatian utama model terjemahan adalah pelestarian jati diri Kristen, sambil berupaya sungguh-sungguh mengindahkan kebudayaan.

Pendeta yang bertugas sebagai gembala jemaat GBI Ngembak dapat memahami dan menerima iringan musik gamelan Jawa digunakan dalam liturgi ibadah di GBI Ngembak sebagai bentuk kontekstualisasi. Dapat dipahami bahwa pemimpin jemaat di GBI Ngembak mendukung upaya mengindahkan kebudayaan lokal yaitu gamelan Jawa sebagai alat musik dalam pelaksanaan ibadah Minggu. Hal tersebut memiliki kesesuaian dengan model terjemahan dari Bevan (2000, p. 8) yaitu perhatian utama model terjemahan adalah pelestarian jati diri Kristen, sambil berupaya sungguh-sungguh mengindahkan kebudayaan.

\section{Kesimpulan}

Kontekstualisasi gamelan Jawa dalam liturgi ibadah di Gereja Baptis Indonesia (GBI) Ngembak terdiri dari satu model, yaitu model terjemahan. Pada model terjemahan tersebut dilakukan melalui upaya pelestarian jati diri Kristen, dengan tetap memperhatikan kebudayaan, perubahan sosial, dan sejarah yang dimiliki oleh Gereja Baptis Indonesia (GBI) Ngembak. Kontekstualisasi gamelan Jawa yang dapat mempengaruhi pertumbuhan iman jemaat dapat dijadikan pemikiran serta usaha supaya budaya lokal dapat terus bertahan.

\section{Kepustakaan}

Bastomi, Suwaji. (1992). Seni dan Budaya Jawa. Semarang: IKIP Semarang Press

Bevans, Stephen B. (2000). Model-model Teologi Kontekstual Jilid 1 Berteologi dalam Konteks. Maumere: LPBAJ.

Bevans, Stephen B. (2000). Model-model Teologi Kontekstual Jilid II Model-model. Maumere: LPBAJ

Darma, Budi. (2011). "Penciptaan Naskah Drama Ambu Hawuk Berdasarkan Tradisi Lisan dan Perspektif Jender”. Jurnal Resital: Jurnal Seni Pertunjukkan, 12(1), 55-64.

Ghofur, Abdul dan Rini, Hartati Sulistyo. (2015). "Komodifikasi Sintren Kumar Budoyo Dalam Arus Modernisasi”. Jurnal Solidarity: Journal of Education, Society and Culture, 4(1), 1-10.

Hapsoro, Leonardus Pandu. (2016). "Identitas Moral: Rekonstruksi Identitas Keindonesiaan pada Era Globalisasi Budaya". Jurnal MASYARAKAT: Jurnal Sosiologi, 20(2), 213-235. 
Hatu, Rauf. (2011). "Perubahan Sosial Kultural Masyarakat Pedesaan (Suatu Tinjauan Teoritik-Empirik)". Jurnal Inovasi: Jurnal Matematika, IPA, Ilmu Sosial, Teknologi dan Terapan, 8(4), 1-11.

Hernawan, Wawan. (2012). "Pengaruh Media Massa Terhadap Perubahan Sosial Budaya Dan Modernisasi Dalam Pembangunan”. Jurnal Kom \& Realitas Sosial, 4(4), 83-96.

Jaeni. (2012). "Komunikasi Estetik dalam Seni Pertunjukan Teater Rakyat Sandiwara Cirebon", Jurnal Panggung: Jurnal Seni \& Budaya, 22(2), 160-168.

Kaesthi, Esih Widya. (2014). "Perubahan Sosial Budaya Masyarakat Di Desa Wisata Karangbanjar Kabupaten Purbalingga". Jurnal Solidarity: Journal of Education, Society and Culture, 3(1), 56-61.

Kango, Andries. (2015). "Media dan Perubahan Sosial Budaya". Jurnal Farabi, 12(1), 2034.

Kirchberger Georg, Boli Ujan Bernardus. (2006). Liturgi Autentik dan Relevan. Ledalero Mumere.

Liliweri, Alo. (2013). Dasar-dasar Komunikasi Antarbudaya. Yogyakarta: Pustaka Pelajar.

Lohanda, Mona. (1983). "Dangdut: Sebuah Pencarian Identitas (Tinjauan Kecil dari Segi Perkembangan Historis)". Dalam Sedyawati, Edi \& Djoko, Sapardi (Ed.). Seni Dalam Masyarakat Indonesia (Bunga Rampai). Jakarta: PT Gramedia.

Martasudjito, E. Pr. (2005). Ekaristi Tinjauan Teologis, Liturgis, dan Pastoral. Yogyakarta: Kanisius.

May, Vanessa. (2011). "Self, Belonging and Social Change”. Jurnal Sociology, 45(3), 363378.

Muniarti. (2015). "Dekonstruksi Estetika dan Makna Musik Gamat di Sawahlunto, Sumatera Barat”. Jurnal Resital: Jurnal Seni Pertunjukkan, 16(1), 25-35.

Murni, Endri Sintiana., Rohidi, Tjetjep Rohendi., Syarif, Muh. Ibnan. (2016). "Topeng Seni Barongan Di Kendayakan Tegal: Ekspresi Simbolik Budaya Masyarakat Pesisiran" dalam Catharsis: Journal of Arts Education, 5(2), 150-159. Semarang: PPS UNNES.

Nafis, Ahmad., Minawati, Rosta., dan Ediwar. (2014). "Estetika Musik Zapin Sebagai Budaya Populer Di Pekanbaru”. Jurnal Bercadik: Jurnal Pengkajian dan Penciptaan Seni, 2(2), 1-14.

Rohidi, Tjetjep Rohendi. (2011). Metodologi Penelitian. Semarang: Cipta Prima Nusantara.

Romadhon, Ali. (2013). "Musik Dangdut Koplo Di Grup Bhaladika Semarang Dalam Konteks Perubahan Sosial Budaya". Jurnal Catharsis: Journal of Arts Education, 2(1), 8-13.

Ruseli, Yeni dan Minawati, Rosta. (2013). "Fenomena Musik Kompang Kecamatan Bengkalis Di Era Globalisasi". Jurnal Bercadik: Jurnal Pengkajian dan Penciptaan Seni, 1(1), 131-140.

Saepudin, Asep. (2015). "Laras, Surupan, dan Patet dalam Praktik Menabuh Gamelan Salendro". Yogyakarta: Resital Vol. 16 No.1. 
Saepudin, Asep. (2015). "Perkembangan dan Perubahan Tepak Kendang Jaipongan Suwanda dalam Masyarakat Urban”. Journal of Urban Society's Arts, 2(1), 9-17.

Setiawati, Debi dan Sanjoyo, Warih Yudo. (2012). "Perubahan Sosial Budaya Desa Purwodadi Kecamatan Barat Kabupaten Magetan Tahun 1990-2010". Jurnal Agastya: Jurnal Sejarah dan Pembelajarannya, 2(1), 66-84.

Siregar, Fuad Habibi dan Kinseng, Rilus A. (2015). "Perubahan Sosial Budaya Dan Tingkat Kesejahteraan Migran Batak Di Sektor Informal Di Kota Bogor". Jurnal Sodality: Jurnal Sosiologi Pedesaan, 3(1), 13-28.

Sitompul, Adelbert Agustin dkk. (1998). Gereja dan Kontekstualisasi. Jakarta: Pustaka Sinar Harapan

Soedarsono, R.M. (1998). Pengaruh Perubahan Sosial terhadap Perkembangan Seni Pertunjukan di Indonesia (Makalah disajikan dalam Simposium Internasional Ilmuilmu Humaniora V di Universitas Gadjah Mada Yogyakarta.

Soeroso. (1993). Bagaimana Bermain Gamelan. Jakarta: Balai Pustaka.

Sugiartha, I Gede Arya. (2015). "Bentuk dan Konsep Estetik Musik Tradisional Bali”. Jurnal Panggung: Jurnal Ilmiah Seni \& Budaya, 25(1), 46-59.

Sumaryanto, F.T. (2007). Pendekatan Kuantitatif dan Kualitatif Dalam Penelitian Pendidikan Seni. Semarang: UNNES PRESS.

Supriyatna, Eddy. (2012). "Sosiologi Seni Untuk Menganalisis Desain Kursi dalam Konteks Budaya Jawa”. Jurnal Mudra: Jurnal Seni Budaya, 27(1), 78-88.

Susantina, Sukatmi. (2001). Inkulturasi Gamelan Jawa: Studi Kasus di Gereja Katholik Yogyakarta. Yogyakarta: Philosophy Press.

Tomatala, Y. (1996). Teologi Kontekstual (Suatu Pengantar). Jawa Timur: Yayasan Penerbit Gandum Mas. 